\title{
Using modified multiple phosphorus sensitivity indices for mitigation and management of phosphorus loads on a catchment level.
}

\section{Paul J. Oberholster ${ }_{1,2}$, Jackie Dabrowski ${ }_{2}$, Anna-Maria Botha $3^{*}$}

With 4 figures and 3 tables

${ }^{1}$ CSIR Natural Resources and the Environment, P.O. Box 320, Stellenbosch 7599, South Africa, email: poberholster@csir.co.za, Phone: +27 21888 2591, Fax: +27 218882693

${ }^{2}$ Department of Paraclinical Sciences, Faculty of Veterinary Science, University of Pretoria, P/Bag X04, Onderstepoort 0110, South Africa, email: jdabrowski1@,csir.co.za, Phone: +27 21 888, 2591, Fax: +27 21888 2693

${ }^{3}$ Department of Genetics, University of Stellenbosch, Private Bag X1, Matieland, Stellenbosch, 7601, South Africa, email: ambo@sun.ac.za Phone: +27 21808 5832, Fax: +27 218085833

${ }^{*}$ Corresponding author

Keywords: river phosphorus sensitivity index (RPSI), lake phosphorus sensitivity index (LPSI), periphyton, river substrate, lake $\mathrm{A} / \mathrm{C}$ diatom ratio, eutrophication

\begin{abstract}
:
The relationships between river and lake phosphorus sensitivity, environmental drivers and catchment characteristics within the upper Olifants River and Lake Loskop were studied over a period of four years to come up with mitigation and management strategies. Using modified indices it was evident that the best strategy for improving the trophic state of Lake Loskop
\end{abstract}


was to drastically reduce the external nutrient loading coming from the upper Olifants River catchment. According to the lake phosphorus sensitivity index (LPSI) developed, Lake Loskop was phosphorus sensitive and will possibly respond to phosphorus reduction in its upper catchment. The river phosphorus sensitivity index (RPSI) developed showed that certain rivers and streams in the upper catchment of Lake Loskop were particularly sensitive to increases in phosphorus $(\mathrm{P})$ loads. The substrate of these rivers and streams consisted of approximately $90 \%$ cobbles or bedrock and showed eutrophic conditions during low flow regimes. The increase in P loads in these streams stimulates the productivity and growth of periphyton dominated by filamentous green algae mats. On the other hand, a restriction of light penetration into the water column by high concentrations of inorganic suspended solids limited the growth of both benthic and planktonic algae in $>3$ order streams dominated by sand or mud bottom substrates, thus making these streams less sensitive to high P loads. Rivers and streams in the upper catchment that required mitigation of $\mathrm{P}$ loads were identified according to the RPSI and different P load management practices were outlined. The findings of this study are important for restoration and management purposes of increased $\mathrm{P}$ loads in conjunction with river characteristics and phytoplankton occurrence. The modified indices developed for P management can be a useful tool in river basins in other parts of the world with the same environmental drivers and catchment characteristics.

\section{Introduction}

Freshwater in a semiarid country like South Africa is a strategic resource and river basins are the basic geographic units for water resource management (DWAF 2004). However, anthropogenic modifications directly or indirectly influence running water ecosystems and have been identified as one of the greatest threats to freshwater resources in South Africa and 
Africa (De Villiers \& Thiart 2007; Nyenje et al. 2010). The situation is aggravated by the fact that South Africa, along with Australia, has the highest regional variability of rainfall and runoff in the world (Hains et al. 1988). The Olifants River (the English translation of the Olifants River is Elephant River) is one of the main river systems in South Africa. It has been described as one of the most polluted rivers in southern Africa, with Lake Loskop acting as a sink for nutients from the upper catchment of the Olifants River system (Oberholster et al., 2010). Catchment management is rapidly being recognized as holding the key to the rehabilitation or protection of degraded lakes (Born 1979). However, the question that arises is at what rate and to what extent the upper Olifants River system and Lake Loskop under study might recover following suitable restoration efforts? Previous studies indicated that implementation measures such as the reduction in nutrient fluxes may not necessarily result in an ecological change back to pre-impacted conditions (Jarvie et al. 2004). According to McDowell et al. (2004), successful restoration and management of water bodies requires knowledge of the phosphorus sensitivity ofthe system and how it will respond to increases or decreases in P loads. Phosphorus sensitivity of rivers are determined by employing physical, chemical and biological processes which influence the transport, transformation and retention of nutrients during downstream transport. The development of phosphorus sensitivity indices are therefore developed to act as decision support tools for assessing river and lake phosphorus sensitivity classification to aid conservation planners and water managers in achieving the ultimate goal to manage and restore phosphorus impacted catchments by reducing high levels of phosphorus loads. Large river systems such as the Olifants River are composed of smaller interconnected sub-catchments, each characterised by longitudinal, vertical and lateral exchanges of water and materials. In such a system, planktonic (suspended in water column) algal biomass and nutrients will increase along the length of a river (Vannote et al. 1980). In the upper reaches of a river in first and second order streams, 
the planktonic algal biomass will not reach nuisance concentrations due to its short retention time (Correll 1998). However, if there exist long periods of hydraulic retention time between flood events (e.g. $\geq 100$ days), eutrophic conditions (e.g. mat formation of benthic filamentous algae) can develop at low $\mathrm{P}$ concentrations of $\leq 0.5 \mu \mathrm{g} \mathrm{l}^{-1}$ (McDowell et al. 2004). The main sources of $P$ for filamentous algae are accessed from the water column since they are mainly attached to river macrophytes or the bedrock substrate. Unavailable forms of $\mathrm{P}$ can be transformed into available forms through sediment interaction in rivers dominated by sand and mud bottom substrates. However, it is unlikely that in rivers with short retention times there will be sufficient time for breakdown processes to transform these forms of $\mathrm{P}$ (Hilton \& Irons 1998).

Biggs (2000) reported that algal communities in oligotrophic streams tend to be dominated by both diatoms and filamentous algae, whereas in eutrophic streams communities tend to be dominated by only filamentous green algae as in the case of the Olifants River (Oberholster 2011a). In large river catchments, lakes form an integrated part of the landscape and also reflect land use in these catchments. Major efforts have been made worldwide to improve the ecological quality of lakes by reducing external nutrient loading (Oberholster et al. 2007; Yang et al. 2008; Abell et al. 2010). These efforts have often resulted in lower lake $\mathrm{P}$ and decreased chlorophyll $a$ concentrations in the euphotic zone with higher light penetration. Publications from the 1970's and 1980's on South African lakes (Toerien 1977; Walmsley \& Butty 1980; Thornton \& Walmsley 1982; Taylor et al. 1984; Pillay 1994) assume implicitly or directly that $\mathrm{P}$ is the yield-controlling nutrient in South African lakes. The effects of nutrient control however, have not usually been so clear cut, particularly in shallow water bodies where interactions in the littoral zone are particularly important. There are many examples where nutrient control has had virtually no effect (Marsden 1989; Sas, 1989; Scheffer 1998). The reason for the latter was due to compensatory 
internal sources of $\mathrm{P}$ in some cases and because of the importance of biological interactions in others. The objectives of this study were to: (1) Determine the sensitivity of the upper Olifants River catchment to increases in $\mathrm{P}$ loads using a variety of modified $\mathrm{P}$ sensitivity indices in combination with river characteristics and phytoplankton occurrence; (2) Identify both small and large order streams in the catchment that show evidence of eutrophication and therefore require mitigation of increased P loads; (3) Outline best management practices to reduce P loads of these rivers and streams; (4) Determine whether Lake Loskop has reached a threshold following increased $\mathrm{P}$ loads and if it will respond to a possible decrease in $\mathrm{P}$ load coming from the upper Olifants River catchment.

\section{Materials and methods}

\section{Study sites in the upper Olifants River and Lake Loskop}

The area covered by the upper Olifants River catchment measures $11,464 \mathrm{~km}^{2}$ with a mean annual precipitation of $683 \mathrm{~mm}$ and a mean annual runoff of 10,780 $\mathrm{Mm}^{3}$ (Midgley et al. 1994). The two main tributaries of the Olifants River are the Wilge and Small Olifants Rivers. It is a summer rainfall region and the vegetation consists of Highveld Grassland in the upper reaches of the catchment and mixed Bushveld and Thornveld (sub-tropical woodland ecoregion with Acacia and other thorny plants) in the lower reaches around Lake Loskop (Mucina \& Rutherford 2006). The river structure varies from a narrow channel with no definite riparian zone up to a 20-30 m wide channel with well-defined riparian vegetation. Stream diversions do occurred as a result of agriculture and mining activities. These activities resulted in severe disturbance of riparian vegetation and an increase in erosion.

To determine the sensitivity to phosphate loads in the upper Olifants River catchment, 50 sampling sites were selected along the main stem of the Olifants River and its tributaries. 


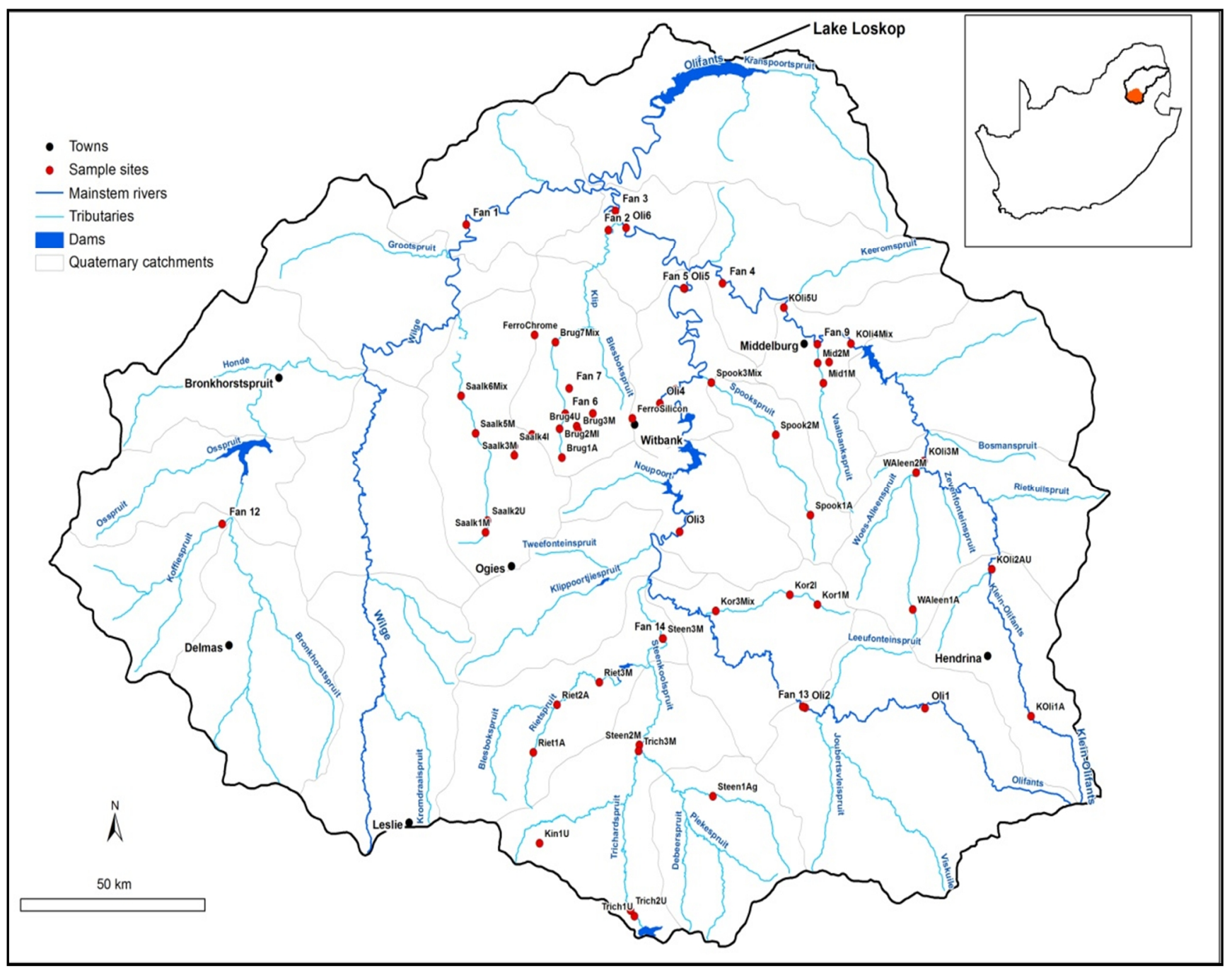

Figure 1. Upper Olifants catchment with 55 selected sampling sites including Lake Loskop.

Sampling of these sites was conducted over a period of two years during high and low flow regimes (Fig 1). These sampling sites included a range of stream orders including lower orders $(\leq 3)$ that function as the source of surface water and sediments for downstream reaches, and higher orders $(\geq 4)$ that transport water and sediment along the main stem with no net gain or loss of materials. To limit the influence of possible longitudinal physical and biological pattern changes within each stream order, we selected more than one sampling site per river or tributary and pooled the data together to present the characteristics for each river or tributary. 
Lake Loskop is a man made lake with a maximam depth of 44 meter in the lacustine zone and a minimum depth of 2 meters in the riverine zone. The lake has an area of 2,427 ha and a volume of $374.3 \mathrm{~m}^{3}$ at full supply capacity. It is the biggest storage unit in the upper Olifants River catchment with $90 \%$ of its water been used for extensive irrigation by the Loskop Irrigation Board, the second largest irrigation scheme in South Africa. Five sites were selected at Lake Loskop from the inflow of the Olifants River to the dam wall to represent a spaciotemporal flow gradient across the lake. These sites were sampled on a monthly basis for four years $(2008-2011)$.

\section{The development of the river phosphorous sensitivity index (RPSI)}

To determine the sensitivity of these rivers or streams to rising $\mathrm{P}$ loads we modified the river classification system developed by Newton \& Jarell (1999) and McDowell et al. (2004). The latter is strongly based on river hydrogeomorphology and hydrology which is in relationship with South African river conditions and characteristics (Rowntree \& Wadeson, 1999, Oberholster, 2011a). In the modified index, we included biotic indicators, such as benthic and planktonic algae based on data of previous findings of three South African river systems which includes the Olifants River (Oberholster 2011a) (Fig 2). According to the study by Oberholster (2011a) frequent floods in the raining season truncate filamentous green algal successional sequence and thereby favouring either tightly attached, resistant forms or those recolonization and growth rates high enough to accumulate biomass between flood periods in the Olifant's River. The study also showed that certain filamentous green algal species was indicators of land use activities and can therefore be used as indicators of pollution during medium and high river flow regimes.In the modified river classification system, algae were selected as bioindicators as they have a short regeneration time and life cycle, allowing the 


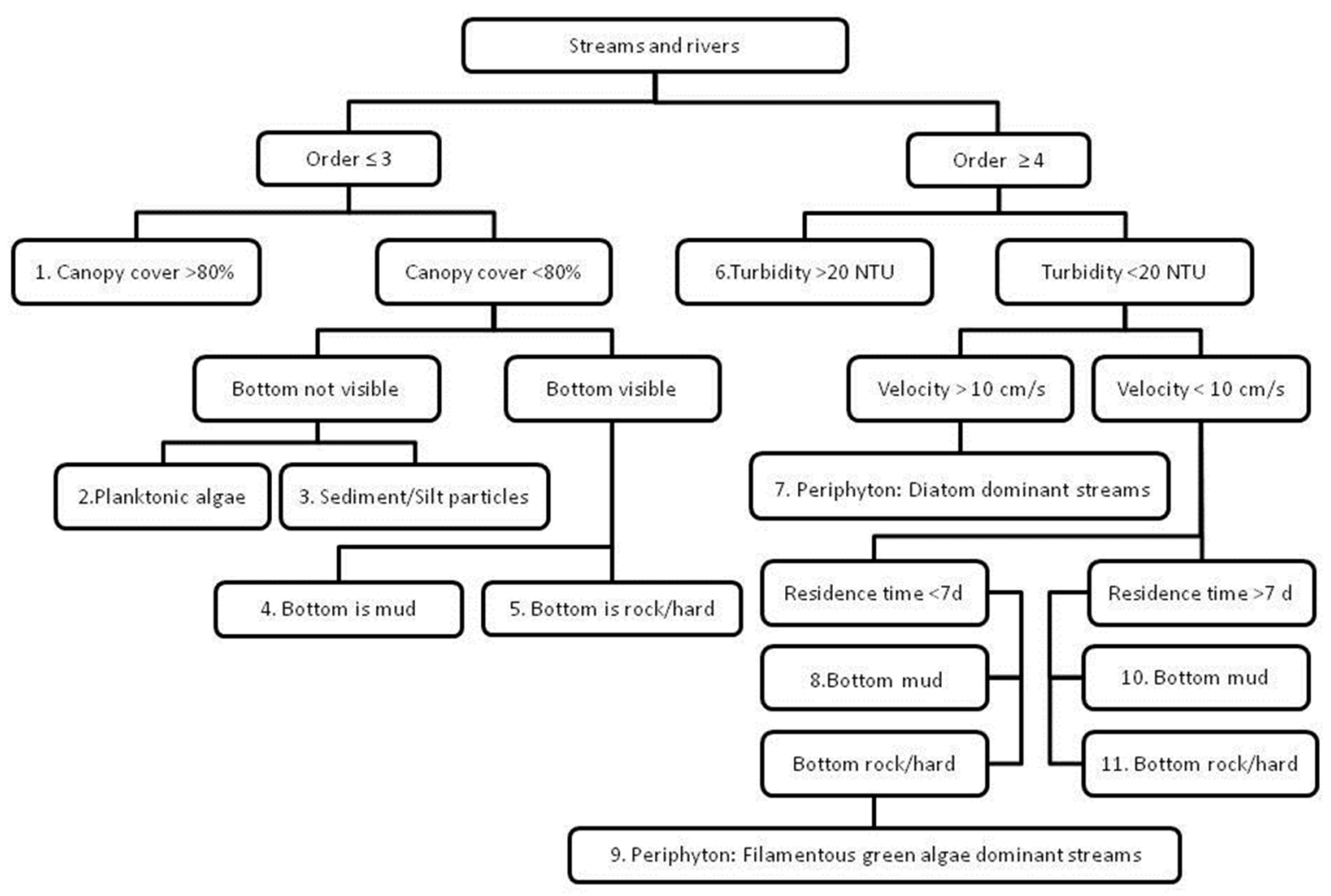

Figure 2. Classification of streams and rivers in the upper Olifants River catchment, numbers 1-11 refer to Table 1 and 2.).

community to respond more quickly to anthropogenic influences like fluctuating phosphorus loads (Cabecinha et al. 2009) than macroinvertebrates. In the developed RPSI we differentiated between turbidity caused by no light penetration of the water column due to increases in planktonic algae and suspended sediment particles in low order streams using data from Koning \& Roos (1999) and trophic state categories of Kalff (2002) (Fig 2). Major land use practices as contributors of P loads in the upper Olifants River were identified using a 1: 50000 map of the area in order to link land uses to best management practices. We identified 8 types of rivers or streams in the Upper Olifants catchment which is summarized in table 1. 
Table 1: River phosphorus sensitivity index modified after McDowell et al. (2004) for restoration and management purposes in relationship with Fig 2. * The following rivers or streams were not detected in the upper Olifants catchment according to Fig 2: 1. Heterotrophic small stream, 8. Rooted macrophyte dominant large streams. 10. Large stream with shifts between phytoplankton and macrophyte dominance. Refer to McDowell et al. (2004) for more information on these streams.

\begin{tabular}{|c|c|c|}
\hline River Description & River Characteristics & Phosphate management scenarios \\
\hline \multirow[t]{2}{*}{$\begin{array}{l}\text { 2. Planktonic algae } \\
\text { dominated small } \\
\text { stream }\end{array}$} & \multirow{2}{*}{$\begin{array}{l}\text { Periphyton light limited due to turbidity caused by planktonic } \\
\text { algae biomass in the water column. Although these streams is } \\
\leq 3 \text { order streams, the resident time is long enough in winter } \\
\text { and early summer months during low flows to form water } \\
\text { column algae blooms. Bottom substrates consist of sand and } \\
\text { mud. }\end{array}$} & $\begin{array}{l}\text { Best management practises: } \\
\text { Decrease P inputs and monitor P, since saturation of sediments eventually can lead to P releases in the water column causing } \\
\text { planktonic algal blooms. }\end{array}$ \\
\hline & & $\begin{array}{l}\text { Land use contributors to } \mathbf{P} \text { loads } \\
\text { Direct input from point source e.g. waste water treatment plants may be important to increases in P loads. }\end{array}$ \\
\hline \multirow[t]{2}{*}{$\begin{array}{l}\text { 3. Non planktonic } \\
\text { algae dominant } \\
\text { small stream }\end{array}$} & \multirow[t]{2}{*}{$\begin{array}{l}\text { Benthic and planktonic algae light limited. Very low algae } \\
\text { biomass. Algae limited due to high turbidity cause by silt or } \\
\text { sediment particles.Resident time short. Bottom substrates } \\
\text { consist of, sand and mud. }\end{array}$} & $\begin{array}{l}\text { Best management practises: } \\
\text { Possible decrease in sediment siltation load, but trophic state may shift to a eutrophic state during low flow periods, once } \\
\text { light limitation is removed. Riparian buffer zone protecting important to prevent river or stream bank erosion. }\end{array}$ \\
\hline & & $\begin{array}{l}\text { Land use contributors to } \mathbf{P} \text { loads } \\
\text { Land clearing for coal mining and agriculture activities. Waste water treatment plants can be important. }\end{array}$ \\
\hline \multirow{2}{*}{$\begin{array}{l}\text { 4. Rooted } \\
\text { macrophyte } \\
\text { dominant small } \\
\text { stream }\end{array}$} & \multirow{2}{*}{$\begin{array}{l}\text { Controlled by vascular plants and macrophytes, which can get } \\
\text { sufficient } P \text { from sediment and mud. Resident time and light } \\
\text { penetration in water column insufficient for algae growth due } \\
\text { to suspended sediment particles in water column. }\end{array}$} & $\begin{array}{l}\text { Best management practises: } \\
\text { Most important is to decrease siltation. A increase in light penetration may cause macrophytes to become colonised by } \\
\text { epiphytes. Efficient P uptake from water or mud by roots meant decrease in P. Siltation can prevent macrophyte growth }\end{array}$ \\
\hline & & $\begin{array}{l}\text { Land use contributors to } P \text { loads: } \\
\text { Coal mining activities and effluent of. waste water treatment plants }\end{array}$ \\
\hline \multirow[t]{2}{*}{$\begin{array}{l}\text { 5. Periphyton } \\
\text { dominant small } \\
\text { stream }\end{array}$} & \multirow[t]{2}{*}{$\begin{array}{l}\text { Respond quickly to changes in phosphorous load as little } \\
\text { bottom sediment is present and the bottom substrate is } \\
\text { dominated by bedrock/ boulders/ stones and gravel. Water } \\
\text { column light penetration high. }\end{array}$} & $\begin{array}{l}\text { Best management practises: } \\
\text { As filamentous algae obtain P directly from the river or stream water column due to the absence of bottom sand and mud, } \\
\text { riparian buffer zones and seepage input may be important. Reduce flow velocities in winter and early summer months can } \\
\text { favour enhanced nutrient retention with longer contact between stream water and bed rock substrate which can enhance } \\
\text { filamentous green algae mat formation. }\end{array}$ \\
\hline & & $\begin{array}{l}\text { Land use contributors to } \mathbf{P} \text { loads: } \\
\text { Land clearing for mining and agriculture activities. }\end{array}$ \\
\hline \multirow[t]{2}{*}{$\begin{array}{l}\text { 6. Heterotrophic } \\
\text { large stream }\end{array}$} & \multirow{2}{*}{$\begin{array}{l}\text { Characterized by high sediment siltation and therefore light } \\
\text { limited. There exist little potential for eutrophication. The } \\
\text { bottom substrate is dominated by sand and clay. }\end{array}$} & $\begin{array}{l}\text { Best management practises } \\
\text { Possible decrease in sediment siltation load, but trophic state may shift to eutrophic states once light limitation is removed. }\end{array}$ \\
\hline & & $\begin{array}{l}\text { Land use contributors to } P \text { loads } \\
\text { Agriculture activities of which feedlots can be important in contribution to P loads. }\end{array}$ \\
\hline \multirow[t]{2}{*}{$\begin{array}{l}\text { 7. Periphyton: } \\
\text { diatom dominant } \\
\text { large stream }\end{array}$} & \multirow{2}{*}{$\begin{array}{l}\text { Medium to high flow regime prevents macrophytes from } \\
\text { establishing. The resident time insufficient for planktonic } \\
\text { algae bloom formation or benthic filamentous green algae } \\
\text { growth. Bottom substrates consist of a mixer of sand, mud and } \\
\text { cobbles which is dominated by benthic diatoms. }\end{array}$} & $\begin{array}{l}\text { Best management practises } \\
\text { Decreasing phosphorous concentrations in the water column, riparian buffer zones and seepage input may be important. } \\
\text { These rivers are more susceptible to sustained phosphorous inputs through sediment uptake, giving it a greater self } \\
\text { purification capacity. }\end{array}$ \\
\hline & & $\begin{array}{l}\text { Land use contributors to } \mathbf{P} \text { loads } \\
\text { Point source from wastewater treatment plants and land clearing for agriculture activities. }\end{array}$ \\
\hline
\end{tabular}


9. Periphyton:

filamentous green algae do

large stream

Residence time of stream/ river is insufficient for planktonic algae growth in the water column but clear enough for filamentous green algae growth. Bottom substrates consist ofbedrock/ boulders.

11. Large stream shifts between water column planktonic algae and periphyton

Sufficient resident time for planktonic algae gowth which could shade out periphyton during winter and summer low flow periods. However, temperature increase and flood pulses flow periods. However, temperature increase and flood pulses
can affect the dominance of filamentous green algae growth. Bottom substrate consist of bedrock/ boulders
Best management practises

As periphyton obtain P directly from the river or stream water column, due to the absence of sand or mud bottom substrate, management of riparian buffer zones and seepage input may be important. Reduce flow velocities in winter and early summer months can favour nutrient retention with longer contact between stream water and bed rock substrate which enhance filamentous green algae mat formation. Phosphorus self-cleaning capacity of these large rivers or streams is only flow floods, filamentous algae detached from bedrock ending up downstream in lakes or water bodies. Phosphorus from detached filamentous algae is set free in lake or water bodies when detached filamentous algae start to decompose.

Land use contributors to $P$ loads

Land clearing for mining and agriculture activities but feedlots and wastewater treatment plants up stream can be important in contribution to $P$ loads.

Best management practises

If little soft sediment is present, then low internal supply of $\mathrm{P}$ is likely and decrease in $\mathrm{P}$ causes quick response from dominance of green filamentous algae to a diatom dominant system.

Land use contributors to $P$ loads

Land clearing for mining and agriculture activities, feedlots and wastewater treatment plants 
Table 2: River phosphorus sensitivity index for the upper Olifant's River catchment for restoration and management purposes in relationship with Fig 2. Total river sampling sites $n=50$.

\begin{tabular}{|c|c|c|c|c|c|}
\hline River Description & $\begin{array}{l}\text { Phosphate } \\
\text { Sensitivity }\end{array}$ & River Name & Turbidity (NTU) & $\begin{array}{l}\text { Dominant algae and mean chlorophyll } a \\
\text { values (suspended } \mu \mathrm{g} \mathrm{I}^{-1} \text {; benthic } \mathrm{mg} \mathrm{m}^{-2} \text { ) }\end{array}$ & $\begin{array}{c}\text { Velocity/ } \\
\text { residence time } \\
\left(\mathrm{cm} \mathrm{s}^{-1}\right)\end{array}$ \\
\hline \multirow{8}{*}{$\begin{array}{l}\text { 2. Planktonic algae dominated small } \\
\text { stream }\end{array}$} & \multirow[t]{8}{*}{ Medium for $\mathbf{P}(\uparrow)$} & (1) Koffie stream tributary of the Wilge River & 26 & Planktonic diatoms (chl- $a 28 \mu \mathrm{g} \mathrm{l}^{-1}$ ) & $\geq 10$ \\
\hline & & (2) Riet stream, tributary of the Olifants River & 24 & Planktonic diatoms (chl- $a 30 \mu \mathrm{g} \mathrm{l}{ }^{-1}$ ) & $\leq 10$ \\
\hline & & (3) Koring stream, tributary of the Olifants River & 22 & Planktonic diatoms (chl- $a 24 \mu \mathrm{g} \mathrm{l}^{-1}$ ) & $\leq 10$ \\
\hline & & (4) Spook stream, tributary of the Olifants River & 24 & Planktonic diatoms (chl- $\left.a 29 \mu \mathrm{g} \mathrm{l}^{-1}\right)$ & $\leq 10$ \\
\hline & & (5) Koring stream, tributary of the Olifants River & 32 & Planktonic diatoms (chl- $\left.a 27 \mu \mathrm{g} \mathrm{l}^{-1}\right)$ & $\leq 10$ \\
\hline & & (6) Trichard stream, tributary of the Olifants River & 36 & Planktonic diatoms (chl- $a \quad 29 \mu \mathrm{g} \mathrm{l}^{-1}$ ) & $\leq 10$ \\
\hline & & (7) Olifants River (Oli1) & 21 & Planktonic diatoms (chl- $a 22 \mu \mathrm{g} \mathrm{l}^{-1}$ ) & $\leq 10$ \\
\hline & & (8) Olifants River (Oli2) & 20 & Planktonic diatoms (chl- $a \quad 30 \mu \mathrm{g} \mathrm{l}^{-1}$ ) & $\leq 10$ \\
\hline $\begin{array}{l}\text { 3. Non planktonic algae dominant } \\
\text { small stream }\end{array}$ & Low for $P(\uparrow)$ & (1) Steenkool stream tributary of the Olifants River & 82 & Planktonic diatoms (chl- $a 8 \mu \mathrm{g} \mathrm{l}^{-1}$ ) & $\geq 10$ \\
\hline \multirow[t]{3}{*}{$\begin{array}{l}\text { 4. Rooted macrophyte dominant small } \\
\text { stream }\end{array}$} & \multirow[t]{3}{*}{ Low for $P(\uparrow)$} & (1) Saalklap stream near the Town of Balmoral & 64 & $\begin{array}{l}\text { Phragmites reed beds } \\
\text { Planktonic diatoms }\left(\mathrm{chl}-a 3 \mu \mathrm{g} \mathrm{I}^{-1}\right)\end{array}$ & $\geq 10$ \\
\hline & & $\begin{array}{l}\text { (2) Vaalbank stream, tributary of the Klein Olifants } \\
\text { River }\end{array}$ & 43 & $\begin{array}{l}\text { Phragmites reed beds } \\
\text { Planktonic diatoms }\left(\text { chl- } a 7 \mu \mathrm{g}^{-1}\right)\end{array}$ & $\geq 10$ \\
\hline & & (3) Klip stream, tributary of the Olifants River & 29 & $\begin{array}{l}\text { Phragmites reed beds and water weed (Isolepis } \\
\text { fluitans) Planktonic diatoms }\left(\mathrm{chl}-a 6 \mu \mathrm{g} \mathrm{l}^{-1}\right)\end{array}$ & $\geq 10$ \\
\hline \multirow[t]{4}{*}{ 5. Periphyton dominant small stream } & \multirow[t]{4}{*}{ High for $P(\uparrow)$} & $\begin{array}{l}\text { (1) Woes-Alleen stream, tributary of the Klein } \\
\text { Olifants River }\end{array}$ & 2 & Benthic filamentous (chl- $a 86 \mathrm{mg} \mathrm{m}^{-2}$ ) & $\leq 10$ \\
\hline & & (2) Steenkool stream, tributary of the Wilger River & 2 & Benthic filamentous algae (chl- $a 131 \mathrm{mg} \mathrm{m}^{-2}$ ) & $\leq 10$ \\
\hline & & (3) Leeufontein stream tributary of the Olifants River & 3 & Benthic filamentous algae (chl- $a 78 \mathrm{mg} \mathrm{m}^{-2}$ ) & $\leq 10$ \\
\hline & & $\begin{array}{l}\text { (4) Dwars-in-die-weg stream, tributary of the } \\
\text { Olifants River }\end{array}$ & 1 & Benthic filamentous algae (chl- $a 91 \mathrm{mg} \mathrm{m}^{-2}$ ) & $\leq 10$ \\
\hline \multirow[t]{2}{*}{ 6. Heterotrophic large stream } & \multirow[t]{2}{*}{ Low for $P(\uparrow)$} & Klein Olifants River (KOLI3M) & 41 & Planktonic diatoms (chl- $a 3 \mu \mathrm{g} \mathrm{l}^{-1}$ ) & $\geq 10$ \\
\hline & & Bronkhorst stream (site 34) & 39 & Planktonic diatoms (chl-a $5 \mu \mathrm{g} \mathrm{l}^{-1}$ ) & $\geq 10$ \\
\hline $\begin{array}{l}\text { 7. Periphyton: diatom dominant large } \\
\text { stream }\end{array}$ & Medium for $P(\uparrow)$ & Wilge River, main stem (site 1) & 5 & Benthic diatoms (chl- $a 28 \mu \mathrm{g} \mathrm{l}^{-1}$ ) & $\geq 10$ \\
\hline \multirow{3}{*}{$\begin{array}{l}\text { 9. Periphyton: filamentous green algae } \\
\text { dominant large stream }\end{array}$} & \multirow[t]{3}{*}{ High for $P(\uparrow)$} & (1) Olifants River (Oli 5) & 19 & Benthic filamentous algae (chl- $a 129 \mathrm{mg} \mathrm{m}^{-2}$ ) & $\geq 10$ \\
\hline & & $\begin{array}{l}\text { (2) Klein Olifants River below Lake Middelburg } \\
\text { (KOLI4Mix) }\end{array}$ & 1 & Benthic filamentous algae (chl- $a 134 \mathrm{mg} \mathrm{m}^{-2}$ ) & $\geq 10$ \\
\hline & & (3) Olifants River (Fan 5) & 9 & Benthic filamentous algae (chl- $a 141 \mathrm{mg} \mathrm{m}^{-2}$ ) & $\geq 10$ \\
\hline \multirow{2}{*}{$\begin{array}{l}\text { 11. Large stream shifts between water } \\
\text { column planktonic algae and } \\
\text { periphyton dominance }\end{array}$} & \multirow[t]{2}{*}{ High for $P(\uparrow)$} & (1) Olifants River (Fan 3) & 12 & Benthic filamentous algae (chl- $a 97 \mathrm{mg} \mathrm{m}^{-2}$ ) & $\geq 10$ \\
\hline & & (2) Lower reaches of the Olifants River (Oli1) & 15 & Benthic filamentous algae (chl- $a 89 \mathrm{mg} \mathrm{m}^{-2}$ ) & $\geq 10$ \\
\hline
\end{tabular}




\section{Physic-chemical sample collection}

The turbidity features of the different river sampling sites were measured in situ at the water surface using a Hach 2100P Turbidimeter (Loveland, USA). Hydrological data from the different sampling stations was obtained from the Department of Water Affairs through the use of permanent flow stations. In certain cases, such as small tributaries where permanent flow station data was not available, an alternative method (Gore 2006) was used to determine stream velocity.

\section{Bottom substrate and canopy cover}

The substratum type of the different rivers and streams (i.e. percentage of cobbles, pebbles, gravel, sand and silt) and substratum cover (i.e. macrophytes) as well as the canopy cover were determined visually according to Stevenson \& Bahls (1999).

\section{Benthic algae sampling}

Three river or stream habitats were sampled for benthic algae, namely: (1) the stone surfaces supporting the epilithon; (2) the sand surfaces supporting the episammon; (3) the silt surface supporting the epipelon. For sampling the epilithon, stones were collected from the submerged part (10-50 cm depth) of the river bank at each sampling site. The attached algae were removed by brushing an area of $5 \mathrm{~cm}^{2}$ of each stone and the material was resuspended in $200 \mathrm{ml}$ deionised water. An aliquot of $50 \mathrm{ml}$ was fixed with formaldehyde at a final concentration of $4 \%(\mathrm{v} / \mathrm{v})$ for microscopic examination to identify algal species. In the case of sand and silt samples containing benthic diatoms, the sediment was cleared of organic matter in a potassium dichromate and sulphuric acid solution and the cleared material was rinsed, diluted, and mounted in Pleurax medium for microscopic examination. 


\section{Planktonic algae sampling}

A scoop bottle sampler (1 litre) was used in streams and rivers where planktonic algae were dominant in the water column. All algae were identified using a compound microscope at 1250 x magnification (Truter 1987; Wehr \& Sheath 2003; Van Vuuren et al. 2006). The samples were sedimented in an algae chamber and were analyzed under an inverted microscope at $1250 \mathrm{x}$ magnification using the strip-count method (APHA 1992). Observations from a Scanning Electron Microscope were carried out to identify doubtful taxa, mainly on centric diatoms. Algal abundance in the epilithon samples was evaluated by counting the presence of each species (as cells in a filament or equal number of individual cells). The Berger-Parker dominance index (Berger \& Parker 1970) was used to measure the evenness or dominance of the algae at each sampling site. However for the river P sensitivity index (Table 1) the authors only distinguished between benthic and planktonic algae without mentioning species, e.g. benthic green filamentous algae or benthic diatoms and planktonic algae.

\section{The development of the Lake Phosphorous sensitivity index (LPSI)}

To determine the $\mathrm{P}$ sensitivity of the man-made Lake Loskop, we combined the inferred $\mathrm{P}$ threshold sensitivity model of Reynolds (2007) and the Araphidineae to Centrales (A/C) diatom ratios in surface sediment of 5 sampling sites of Lake Loskop (Stockner 1971). TP, chlorophull $a$ (chl- $a$ ) and Secchi disc variables used in the development of the LPSI were within the ranges suggested by Warmsley (1984) and Du Plessis et al. (1990) for the trophic classification of South African impoundments. According to Stockner \& Benson (1967) the $\mathrm{A} / \mathrm{C}$ ratio in surface sediment from deepwater cores is a sensitive indicator of lake trophic state. In the LPSI we used a weight of evidence type approach, with a single cumulative value out of 17 points. The scoring categories used for this modified index were Oligotrophic $\geq 6$; 
Table 3: The modified lake phosphorus sensitivity index for restoration and management purposes.

\begin{tabular}{|c|c|c|c|c|}
\hline Category & $\begin{array}{c}\text { TP mg P } \\
\mathrm{m}^{-3}\end{array}$ & $\begin{array}{c}\text { Months with an average } \\
\text { secchi depth of } \geq 2 \text { meters }\end{array}$ & $\begin{array}{c}\text { Average suspended } \\
\text { chlorophyll a }\left(\mathrm{mg} \mathrm{m}^{-3}\right)\end{array}$ & $\begin{array}{l}\text { Index } \\
\text { Score }\end{array}$ \\
\hline Ultraoligotrophic & $\leq 3$ & Always & $\leq 2$ & 1 \\
\hline Oligotrophic & $3-10$ & $9-12$ months per year & $2-3.5$ & 2 \\
\hline Mesotrophic & $10-35$ & 4-9 months per year & $3.5-9$ & 3 \\
\hline Eutrophic & $35-100$ & $\leq 4$ months per year & $9-25$ & 4 \\
\hline Hypertrophic & $\geq 100$ & Never & $\geq 25$ & 5 \\
\hline \multicolumn{5}{|l|}{ Diatom ratio $\mathrm{A} / \mathrm{C}$ in sediment: } \\
\hline Oligotrophic & $0-1.0$ & & & 1 \\
\hline Mesotrophic & $1.0-2.0$ & & & 2 \\
\hline Eutrophic & $\geq 2.0$ & & & 3 \\
\hline $\begin{array}{l}\text { Hydraulic retention time. TP } \\
\text { sensitive }\end{array}$ & \multicolumn{3}{|c|}{ More than 30 days } & 1 \\
\hline $\begin{array}{l}\text { Hydraulic retention time. } \\
\text { Insensitive to TP loads }\end{array}$ & \multicolumn{3}{|c|}{ Shorter than 3 days } & 3 \\
\hline $\begin{array}{l}\text { Hydraulic retention time. } \\
\text { Slightly TP sensitive }\end{array}$ & \multicolumn{3}{|c|}{ Longer than 3 days and shorter than 30 days } & 2 \\
\hline Bicarbonate alkalinity & \multicolumn{3}{|c|}{$\leq 0.4$ meq $^{-1}$} & 1 \\
\hline Bicarbonate alkalinity & \multicolumn{3}{|c|}{$\geq 2 \mathrm{meq} \mathrm{l}^{-1}$} & 3 \\
\hline Bicarbonate alkalinity & \multicolumn{3}{|c|}{$0.4<2 \mathrm{meq}^{-1}$} & 2 \\
\hline $\begin{array}{l}\text { Surface sediment cover and } \\
\text { water depth. TP sensitive }\end{array}$ & \multicolumn{3}{|c|}{$15 \%$ of the surface sediment cover $<5 \mathrm{~m}$ deep } & 1 \\
\hline $\begin{array}{l}\text { Surface sediment cover and } \\
\text { water depth. Insensitive to TP } \\
\text { loads }\end{array}$ & \multicolumn{3}{|c|}{$\geq 50 \%$ of the lake is shallower than $5 \mathrm{~m}$ deep } & 3 \\
\hline $\begin{array}{l}\text { Surface sediment cover and } \\
\text { water depth. Slightly TP sensitive }\end{array}$ & \multicolumn{3}{|c|}{ Lakes where $\geq 15 \%$, but $\leq 50 \%$ is under $5 \mathrm{~m}$ deep } & 2 \\
\hline Total score & & & & 17 \\
\hline
\end{tabular}

Mesotrophic 7-11 and Eutrophic 12-17 (Table 3). The Reynolds (2007) method assigns scores to different categories of trophic state, hydraulic retention time, bicarbonate availability and the extent of shallow lake sediments that are likely to exchange P. The lower the assigned score, the more likely that the lake will respond to reduction of phosphorus loads from the upper catchment. In the modified lake index we also incorporated Secchi disc data as a measure of light penetration which was excluded from the Reynolds (2007) method. To standardise values for trophic state in relation to Secchi disc depth we made use of data from previous studies of different freshwater man-made lakes in other countries and South Africa, as well as data collected over the past four years from Lake Loskop (Gieskes 1960; Butty et al. 1980; Breen 1983; Chutter 1989; Truter 1987; Zohary \& Breen 1989; DU Plessis et al. 
1990; Kalff 2002; Hart 2006; Das et al. 2009; Oberholster et al. 2007; 2009; 2010; 2011b)

(Table 3). In the Stockner \& Benson (1967) method the $\mathrm{A} / \mathrm{C}$ ratio is based principally on the major shift in planktonic diatoms from an initial dominance by centrales (C) towards an increasing abundance of araphidinate diatoms (A). The latter as well as Reynolds (2007) threshold model and Secchi disc values were incorporated in the developed LPSI.

\section{Diatom $\mathrm{A} / \mathrm{C}$ ratio}

According to Bellinger and Sigee (2010) the ratio of araphid pinnate/centric diatoms provides a good example of the successful use of a broad taxonomic index in a particular lake situation. Bellinger and Sigee (2010) also indicated that analysis of indicator diatoms within sediment cores has been particular useful in monitoring water quality and setting targets for specific restoration processes. We selected the $\mathrm{A} / \mathrm{C}$ ratio index as part of the LPSI for the following reasons (a) To verify the existing trophic states of the lake, that will be compared in the future with the lake's trophic states after nutrient reduction programmes and mitigation activities are set in place for phosphorus sensitivity streams and rivers in the upper Olifants River catchment; (b) Because very little is known about the limnological history of Lake Loskop, the only previous study was done in 1978 by Butty et al. (1980); (c) To determine algal assemblage over space and time. Due to our sampling intervals on a monthly basis, the possibility exists that phytoplankton community changes may occurred undetected, since Reynolds (1984) reported that disturbances at up to 10-day intervals can initiate a succession sequence in phytoplankton development. Therefore, sampling of the bottom sediment of Lake Loskop may capture changes in phytoplankton assemblage, not detected during our monthly sampling intervals; (c) The dominant planktonic diatom species observed in the water column of Lake Loskop was in association with the dominant species reported by Stockner (1971) in his $\mathrm{A} / \mathrm{C}$ index. 


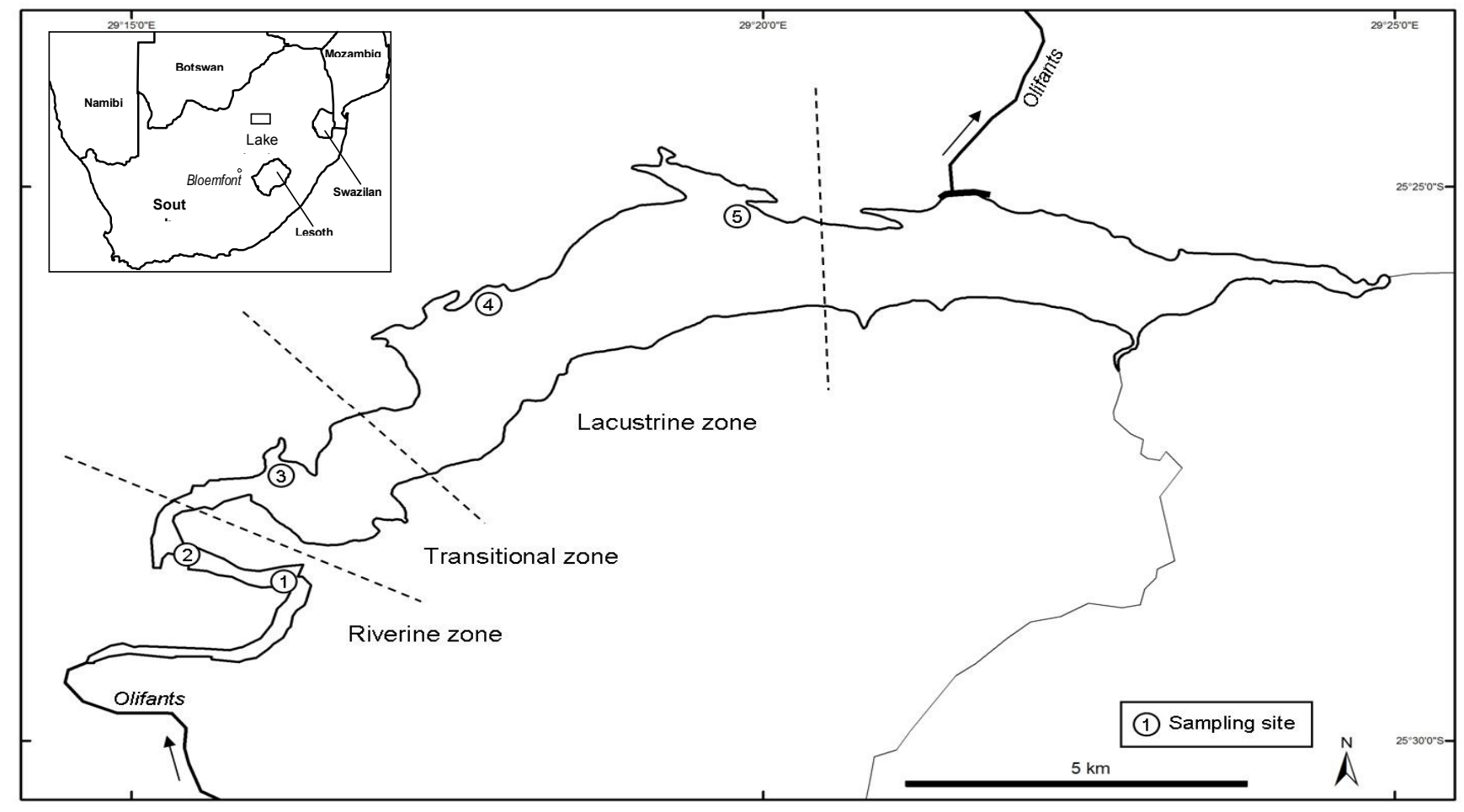

Olifants River. Inset shows the location of the map area in South Africa. (Map adapted from Oberholster et al., 2010).

To determine the $\mathrm{A} / \mathrm{C}$ diatom ratio's, diatoms in deepwater surface sediment of Lake Loskop were sampled with a grab sampler $(10 \mathrm{~cm}$ depth) at the 5 sampling sites once a season over a period of four years to determine $\mathrm{A} / \mathrm{C}$ ratios (Table 3 and 4, Fig 3). All diatom identifications in the bottom sediment were made by using a compound microscope at $1250 \mathrm{x}$ magnification to species level (Truter 1987; Van Vuuren et al. 2006; Wehr \& Sheath, 2003). All counts were based on numbers of cells observed and the individual data grouped into major planktonic groups $\mathrm{A} / \mathrm{C}$ after clearing in acid persulfate. Community comparisons of all study sites in each sampling event were made according to Brower et al. (1990). 


\section{Chlorophyll $a$; chemical analyses and water column transparency}

To determine chl $-a$ and water chemistry of Lake Loskop, five integrated water samples at 5 sites were taken over a period of four years $(n=36)$ from the top $2 \mathrm{~m}$ of the water column (epilimnion) using a $4 \mathrm{~cm}$ internal diameter weighted polyethylene hose (Fig 3). All samples were stored in acid washed polyethylene bottles and kept cool in the dark during the two hour transfer from the field to the laboratory. On return to the laboratory the integrated water samples were divided into subsamples for chl $-a$ determination and chemical analyses. The subsamples for chemical analyses were filtered through $0.45 \mu \mathrm{m}$ pore size Whatman GF filters and stored in polyethylene bottles that had been pre-rinsed with dilute sulfuric acid (to $\mathrm{pH}$ 2.0) for analysis of dissolved nutrients and Bicarbonate alkalinity analysis. All analyses were carried out according to standard methods (APHA, AWWA \& WPCF 1992) at the CSIR's accredited analytical laboratory.

Concentrations of total nitrogen (TN) and total phosphorus (TP) were determined using the persulphate digestion technique. Nitrate concentrations were determined on an autoanalyzer with the cadmium reduction method, while SRP concentrations were determined by the ascorbic acid method (APHA, AWWA \& WPCF 1992). Chlorophyll $a$ (chl-a) was extracted from lyophilized Whatman GF filters using N,N-dimethylformamide for two hours at room temperature and measured spectrophotometrically at $647 \mathrm{~nm}$ and 664 nm according to Porra et al. (1989). Secchi depth (light transparency of the euphotic zone) in Lake Loskop was measured at all five sampling sites with a $20 \mathrm{~cm}$ black and white Secchi disc. To distinguish between turbidity caused by planktonic algae and suspended sediment particles in $\leq 3$ order streams, suspended chlorophyll was measured according to Porra et al. (1989). This data were included in Table 4. 
Table 4: The mean physical, chemical and biological parameters of the different sampling sites at Lake Loskop over a period of 4 years before the data was incorporated into the lake index (Table 3). Total lake sampling sites $n=5$.

\begin{tabular}{|c|c|c|c|c|}
\hline Season: & Autumn & Winter & Spring & Summer \\
\hline \multicolumn{5}{|l|}{ Parameter: } \\
\hline TP $\mathrm{mg} \mathrm{P} \mathrm{m}^{-3}$ & $20.3 \pm(3.4)$ & $12.1 \pm(1.1)$ & $21.2 \pm(4.2)$ & $37.6 \pm(6.5)$ \\
\hline $\begin{array}{l}\text { Months with an average Secchi } \\
\text { depth of } \geq 2 \text { meters (average Secchi } \\
\text { during different seasons) }\end{array}$ & $2.5 \pm(0.7)$ & $5.4 \pm(0.2)$ & $2,8 \pm(0.8)$ & $0.78 \pm(0.9)$ \\
\hline $\begin{array}{l}\text { Average suspended chlorophyll a } \\
\left(\mathrm{mg} \mathrm{m}^{-3}\right)\end{array}$ & $6.4 \pm(1.1)$ & $2.8 \pm(0.5)$ & $5.2 \pm(0.9)$ & $18.4 \pm(2.1)$ \\
\hline Diatom ratio $\mathrm{A} / \mathrm{C}$ in sediment & $3.4 \pm(0.5)$ & $2.1 \pm(0.1)$ & $2.9 \pm(0.7)$ & $4.2 \pm(1.2)$ \\
\hline Hydraulic retention time & \multicolumn{4}{|c|}{ $\pm 0.5(0.09)$ year } \\
\hline Bicarbonate alkalinity meq $\mathrm{I}^{-1}$ & $1.6 \pm(0.4)$ & $0.9 \pm(0.1)$ & $1.2 \pm(0.6)$ & $2.2 \pm(0.4)$ \\
\hline $\begin{array}{l}\text { Surface sediment cover and water } \\
\text { depth. }(\%)\end{array}$ & $7.2 \pm(1.8)$ & $15.3 \pm(3.4)$ & $10.2 \pm(2.2)$ & $5.2 \pm(1.4)$ \\
\hline
\end{tabular}

\section{Data analysis}

In this study all river, stream and Lake data generated over the different sampling periods were pool together and mean values were incorporated in to the developed RPSI and LPSI.

\section{Results}

\section{Assessing river catchment phosphorous sensitivity using the RPSI}

All data generated over a period of 2 years are incorporated in the RPSI and presented in Table 2. Based on these data the following selected streams (order $\leq 3$ ) in the upper Olifants River catchment during high and low flow, were classified as highly sensitive to increased levels of $\mathrm{P}$ (Table 1; 2; description of river or stream no. 5). These streams were the WoesAlleen and Leeufontein streams (both tributaries of the Klein Olifants River) the Dwars-indie-weg stream (a tributary of the Olifants River) and the Steenkool stream (a tributary of the Wilge River). The average turbidity measured during different flow regimes of these small order streams was low $(\leq 3 \mathrm{NTU})$ in comparison to less sensitive $\mathrm{P}$ streams in the upper Olifants River catchment (Table ). The substrate of these P sensitive streams consisted mainly of bedrock. The algal assemblage of these streams was dominated by mats of filamentous 
green algae (Cladophora glomorata; average benthic chl- $a>78 \mathrm{mg} \mathrm{m}^{-2}$ ) attached to the bedrock.

Large rivers with stream orders greater than four that showed characteristics of eutrophication and phosphorus sensitivity included the Olifants River (site Oli 5), Klein Olifants River below Lake Middelburg (site KOLI4Mix) and the Olifants River (site Fan 5) (Table 1; 2; description of stream or river no. 9). Residence time of these large rivers was insufficient for planktonic algal growth in the water column but light transparency was clear enough $(\leq 5 \mathrm{NTU})$ for periphyton growth. The bottom substrate of these river stretches was predominantly bedrock or boulders and was dominated by green filamentous algae $(C$ glomorata) attached to the substrate. The average benthic chl- $a$ values of these river stretches indicated eutrophic conditions according to Kalff (2002) Other sampling sites in the lower reaches of the Olifants River that showed a possible high sensitivity to increase in P loads were sites Fan 3 and Oli1 (Table 1; 2; description of stream or river no. 11). At these sites there was sufficient resident time for planktonic algae to shade out periphyton during the summer months. However, temperature $\left(\geq 28^{\circ} \mathrm{C}\right)$ and flood pulses also affected the periphyton attachment and growth, especially green filamentous algal mats (C. glomorata), causing large stream shifts between planktonic algae and periphyton at these sites. Rooted macrophytes dominated small streams, e.g. the Saalklap stream, the Vaalbank stream (a tributary of the Klein Olifants River) and the Klip stream (a tributary of the Olifants River) were dominated by Phragmites australis reed beds. In the Klip stream, water weed (Isolepis fluitans) was also observed in small isolated patches (Table 1, 2; river or stream description no. 4.)

The substrate of planktonic diatoms dominated small streams (e.g. the Koffie, Koring, Spook and Riet streams) consisted mainly of mud and fine sand. These small streams were not light limited due to canopy cover, but rather light limited due to turbidity caused by the 
flow regime (Table 1, 2 river and stream order no. 2). The turbidity ( $>20$ NTU) prevented the dominance of macrophytes and benthic green filamentous algae in these streams. Although the residence time of these streams was less than seven days and their velocity greater than 10 $\mathrm{cm} \mathrm{s}^{-1}$, it was evident that the water column was dominated by low numbers of centric

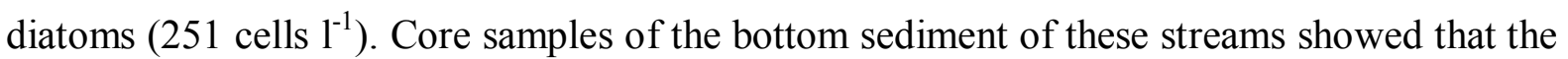
benthic diatom Synedra ulna Kützing was the dominated species. The latter is a epiphytic diatom species that was possibly washed in from upstream (Taylor et al. 2007). Based on the results obtained, it was clear that the dominant diatom species sampled from the water column (Cyclotella meneghiniana Kützing and Melosira varians Agardh) were indicators of nutrient enrichment (Van Vuuren et al. 2006). However, due to the turbidity and low light penetration caused by the flow regime, as well as the substrate of these streams that consists of sand that act as a sink for phosphorus, the risk of increased P loads to these streams was medium. These observations in $\leq 3$ order streams were also in agreement with our observations on large periphyton diatom dominated rivers with a stream velocity $\geq 10 \mathrm{~cm} \mathrm{~s}^{-1}$. The description of large and small streams, and their characteristics as well as their required mitigation for P loads (High, medium or low sensitivity for increases in P loads) are set out in Tables 1 and 2 that also outlines best management practices for P loads of these streams.

\section{Assessing the phosphorous sensitivity of Lake Loskop using the LPSI}

Substantial data sets were collected over a period of four years to classify Lake Loskop into one of the five trophic classes set out in the LPSI (Table 4). All data generated over the 4 year sampling periods of the 5 sampling sites were pooled together and presented in Table 4 . These data were incorporated into the LPSI to determine the trophic status and sensitivity to increase in P loads of Lake Loskop (Table 5). the lake (. It was evident from the LPSI category scores (between 7-1) that Lake Loskop was on the boarder of meso-eutrophic and 
Table 5 The actual index score which includes data of the different sampling sites in Lake Loskop sampled over a period of 4 years.

\begin{tabular}{|c|c|c|c|c|c|}
\hline Category & TP mg P m $\mathbf{m}^{-3}$ & $\begin{array}{c}\text { Months with an } \\
\text { average secchi depth } \\
\text { of } \geq 2 \text { meters }\end{array}$ & $\begin{array}{l}\text { Average suspended } \\
\text { chlorophyll a }\left(\mathrm{mg} \mathrm{m}^{-3}\right)\end{array}$ & $\begin{array}{l}\text { Index } \\
\text { Score }\end{array}$ & $\begin{array}{l}\text { Actual } \\
\text { Score }\end{array}$ \\
\hline Mesotrophic & $10-35$ & 4-9 months per year & $3.5-9$ & 3 & 3 \\
\hline \multicolumn{6}{|l|}{$\begin{array}{l}\text { Diatom ratio } \mathrm{A} / \mathrm{C} \text { in } \\
\text { sediment: }\end{array}$} \\
\hline Eutrophic & \multicolumn{3}{|l|}{$\geq 2.0$} & 3 & 3 \\
\hline $\begin{array}{l}\text { Hydraulic retention } \\
\text { time. TP sensitive }\end{array}$ & \multicolumn{3}{|c|}{ More than 30 days } & 1 & 1 \\
\hline $\begin{array}{l}\text { Bicarbonate } \\
\text { alkalinity }\end{array}$ & \multicolumn{3}{|l|}{$0.4<2$ meq $^{-1}$} & 2 & 2 \\
\hline $\begin{array}{l}\text { Surface sediment } \\
\text { cover and water } \\
\text { depth. TP sensitive }\end{array}$ & \multicolumn{3}{|c|}{$15 \%$ of the surface sediment cover $<5 \mathrm{~m}$ deep } & 1 & 1 \\
\hline Total score & & & & 17 & 10 \\
\hline
\end{tabular}

will still possibly respond to decreases in P loads from the upper catchment (Table 5). For Lake Loskop to return to an oligotrophic state, the following management and restoration activities are suggested (a) Waste water or effluents produced by or resulting from the use of water for industrial purposes in the upper catchment should not contain soluble orthophosphate at a higher concentration than $1.0 \mathrm{mg} \mathrm{l}^{-1}$; (b) The protection of river buffer zones in areas classified by the RPSI as highly sensitive to increased levels of P; and (c) Management of terrestrial land use activities e.g. land clearing for coal mining and agriculture activities in P sensitive sub-catchments with high run off. Various parameters at the selected sampling sites in Lake Loskop differed over seasons between sites for each sampling trip. Some of the data from certain sampling periods is discussed in more detail below.

The deepest light penetration in the euphotic zone (4.7 meters) measured using a Secchi disc was observed in the winter and spring months of July and August 2009 during the clear water phase. However, in February 2008-2011 two of the sampling sites had a Secchi disc depth of less than $10 \mathrm{~cm}$ caused by large blooms of Microcystis aeruginosa Kützing and Ceratium hirundinella Müller. The measured water column depth indicated that less than $15 \%$ of the Lake had a depth of $<5$ meters during the entire study period. The lowest lake 
water depth measured was during the winter season July 2008 in the riverine zone of Lake Loskop ( 3 meters), while the deepest lake depth of 44 meters over the 4 year sampling period was recorded during March 2011 at the dam wall.

The average diatom $\mathrm{A} / \mathrm{C}$ ratio in the first $10 \mathrm{~cm}$ of bottom sediment of the five sampling sites indicated dominance by the araphidinate diatom Fragilaria crotonensis Kitton (average 179 cells $\mathrm{cm}^{2}$ ) and in much lower numbers (average 41 cells $\mathrm{cm}^{2}$ ) the centric diatom Cyclotella meneghiniana Kützing . The average A/C ratio data $(3.2>2.0)$ collected over a period of 4 years at all 5 sampling sites indicated that Lake Loskop falls within the eutrophic category according Stockner (1971). Although this index was not previously employed under South African lake conditions, we did observed a strong relationship between the different seasonal trophic conditions and the sediment diatom assemblage (first 2 cm of bottom sediment samples) especially in the late summer and autumn months (Table 4).

\section{Discussion}

\section{Rivers and stream substrate and responses to phosphorus loads}

In the upper Olifants River catchment very few streams were dominated by rooted macrophytes. On the basis of Grime's model, Biggs (1996) predicted that no macrophytes would grow in rivers with a high frequency of flood flows, unstable bed sediments and high interspaced water velocities as observed at most sites in the Olifants River. However, a decline in water velocity during low flows in winter and early summer can cause the dominance of periphyton followed by macrophytes in most stable conditions as in the case of the low order rooted macrophyte-dominated (Phragmites australis) streams (e.g. the Saalklap stream and Vaalbank stream, a tributary of the Small Olifants River). According to Carignam (1982), the percentage of $\mathrm{P}$ taken up by macrophyte roots in comparison to the whole plant 
differs substantially. His study indicated that $27 \%$ of the $\mathrm{P}$ was driven from the sediment while $72 \%$ of total uptake was from the roots, which make streams dominated by rooted macrophytes less sensitive for rapid P increases as also indicated by McDowell et al. (2004).

Periphyton was included in the RPSI, since it is an important component of the aquatic system of low-order streams in the upper Olifants River catchment (; Oberholster 2011a). In the upper Olifants River catchment benthic algae were mostly dependent on frequent changes in discharge and the intervals between the last flood events. Stone or bedrock attached filamentous algae such as C. glomorata, which can only access nutrients from the water column were good indicators for $\mathrm{P}$ sensitive river sections. This filamentous green algal species was dominant at most sampling sites that were characterized in the index as highly sensitive for increases in P loads. Conversely, periphyton such as benthic diatoms, which are able to access nutrients from both the sediment and the water column, were good indicators for medium P sensitivity for increased P loads (Caput et al., 2005). These medium P sensitivity river and stream stretches in the upper Olifants River catchment had also predominant sand and mud substrates and average flow velocity of $\geq 10 \mathrm{~cm} \mathrm{~s}^{-1}$. From our study it was evident that three of the key factors when determining the P-sensitivity of a river or stream in the upper Olifants River system were the difference in bottom substrate in relationship with benthic algal biomass and the flow regime. This corresponds with previous studies by Bothwell (1989) and Kjeldsen (1994) who found that peak benthic algal biomass on fine grained sediment from 12 stream reaches correlated positively with stream water $\mathrm{P}$ concentrations.

Reduced river flow velocities favour enhanced nutrient retention as a result of greater water retention times within a river reach (Withers \& Jarvie 2008). This longer contact times between stream water and the bottom substrates cause higher rates of periphyton growth and therefore biological $\mathrm{P}$ uptake as in the case of sampling sites Oli5 and Fan 5. Nutrient 
concentrations e.g. total water column $\mathrm{P}$ concentrations was not included as a chemical parameter in the RPSI as in the case of Newton \& Jarell (1999) and McDowell et al. (2004). Moreover, Lakshminarayana (1965) showed in his study that measured water column nutrient concentrations in rivers can decrease with increases of phytoplankton density, giving a lower measured value of the actual original concentrations of nutrients in the water column as chemical indicator. Therefore, at higher phytoplankton densities, phytoplankton could have sequestered nutrients and decreased nutrient concentrations as they settled or were transported downstream. From the data generated in our study, it was evident that the inclusion of benthic and water column algae as bioindicators in conjunction with other river characteristics (e.g. resident time and bottom sediment) can be a useful tool to assess for river or stream stretches that are sensitive to increased P loads. It was evident from our study that the benthic chl- $a \mathrm{mg} \mathrm{m} \mathrm{m}^{-2}$ and suspended chl- $a$ in $\mu \mathrm{g} \mathrm{l^{-1 }}$ were in relationship with the low, medium and high sensitivity to increases in phosphorus loads of rivers and streams in the upper Olifants catchment.

\section{Lakes sensitivity to increase in phosphorus loads}

Once a lake become eutrophic, it is very difficult to restore it to its original form by simply decreasing external phosphorus inputs in its watershed. However, the LPSI developed showed that Lake Loskop score of 10 still falls within border of the meso-eutrophic states range. Carpenter et al. (1999) classified eutrophic lakes with respect to their responses to P sensitivity as follows: (a) responsive (recovery is immediate and proportional to the reduction in P input); (b) hysteretic (recovery requires extreme reductions in $\mathrm{P}$ inputs for a long period of time); (c) irreversible (recovery cannot be accomplished by reducing $\mathrm{P}$ inputs alone). Previous studies have shown that with regard to lake eutrophication control measures as a general rule, deep lakes that stratify permanently throughout the summer season, typically 
respond rapidly to reductions in nutrient loads, whereas in the case of shallow lakes it can take up to decades to recover (Hilton et al. 2006). According to the LPSI, Lake Loskop had only $9 \%$ of the bottom sediment covered with a water depth less than 5 meters making the lake less vulnerable to whole lake wind mixing. However, Hilton et al (2006) showed in their study that the internal cycling of phosphates from the bottom sediment into the lake water column plays a key role in limiting recovery.

There is many documented studies where lakes have responded positively to nutrient load reductions (Marsden 1989; Jeppesen et al. 2005). Analyses of 35 case studies of American and European lakes based on extended time-series data revealed that although internal P loading does delay recovery, new equilibriums with respect to TP were reached in most lakes after $\leq 10-15$ years. This time frame was marginally dependent on lake retention time and depth (Jeppesen et al. 2005). However, positive effects may not always occur after nutrient input reduction. According to Sas (1989) and Marsden (1989), several lakes have been resistant to loading reductions of TP and were slow to recover. This resistance can be due to high P concentrations released from the bottom sediment. Jeppesen et al. (2000) and Sas (1989) indicated from their studies that freshwater lakes will not respond to reduction of $\mathrm{P}$ unless it is below $0.05-0.1 \mathrm{mg} \mathrm{P}^{-1}$ for shallow lakes and $0.02-0.03 \mathrm{mg} \mathrm{P}^{-1}$ in the case of deep lakes. The latter ranges of 0.02-0.03 $\mathrm{mg} \mathrm{P}^{-1}$ falls within the ranges measured for Lake Loskop. Although a wide variety of techniques have been developed for the purpose of lake restoration they are still complex ecosystems with unique interrelationships between physical, chemical and biological properties.

Despite the large amount of work that has been carried out on eutrophication in South African reservoirs and man-made lakes, our collective understanding of eutrophication and light limitation remains extremely difficult. Most South African man-made lakes are turbid containing high concentrations of suspended silts and clays due to upper catchment 
mismanagement, erosion, siltation and unstable riverbeds. This can easily lead to a false sense of security regarding eutrophication in these man-made lakes, since the conventional chlorophyll-nutrient relationship is significantly weakened in comparison with clear-water systems (Hart 2006). High suspended sediment exerts an adverse effect by generating an underwater light climate that favours cyanophytes such as Microcystis aeruginosa which can develop seasonally or episodically under certain hydrological conditions, even in waters that are otherwise characterised by low algal standing stocks, principally as a consequence of light limitation (Hart 2006). From our Secchi disc data ( \pm 8 months of the year a Secchi disc reading of $\geq 2$ meters) and suspended chl- $a$ analyses it was evident that light penetration in the water column of Lake Loskop was governed by planktonic algae biomass rather than high concentrations of suspended silts and clays.

According to Bellinger and Sigee (2010) diatoms within lake sediment have been particularly useful bioindicators, since continuous sedimentation of phytoplankton from the surface water of lakes leads to the build-up of sediment, with the accumulation of both planktonic and benthic phytoplankton. The ratio of Araphidineae to Centrales $(\mathrm{A} / \mathrm{C})$ calculated from deepwater sediment counts of Lake Loskop as well as the dominant diatom species appears to be in agreement with previous studies of the meso-eutrophic Lake Washington (USA) and Windermere (UK). In Lakes Washington and Windermere the Araphidineae group (Asterionella formosa followed by Fragilaria crotonensis) increased markedly after human watershed disturbance and sewage discharge whereas centrale diatoms diminished to the point of rarity (Stockner 1971). In a more recent study conducted by Carney et al. (1994), it was showed that A/C diatom ratio's paralleled contemporary indicators of the trophic transition in Lake Tahoe in the United States. The latter also indicated an decrease in Secchi depth and a increase in $\mathrm{NO}_{3}$. 


\section{Conclusion}

It was evident from the study that although Lake Loskop was nearing the $\mathrm{P}$ threshold to become eutrophic the best strategy for improving its trophic status is the drastic reduction in external nutrient inputs from the upper catchment. The study also showed that Lake Loskop will probably respond to reduction of $\mathrm{P}$ loads if best management practices are applied to reduce $\mathrm{P}$ loads of $\mathrm{P}$ sensitive river stretches. Rivers and streams in the upper Olifants River catchment that were particularly sensitive to increases in phosphors loads and that required mitigation of $\mathrm{P}$ loads were streams consisting of approximately $90 \%$ cobbles or bedrock. The increase in $\mathrm{P}$ loads in these streams stimulates the productivity and growth of benthic algae (commonly called periphyton). Restriction of light penetration into the water column by high concentrations of inorganic suspended solids limits the growth of both benthic and planktonic algae in certain stretches of the studied streams and rivers making them less $\mathrm{P}$ sensitive. From the study it was evident that the inclusion of benthic and water column algae as bioindicators in conjunction with river characteristics can be a useful tool to identify stretches of rivers or streams as candidates for P mitigation measures.

\section{Acknowledgements}

The authors also want to thank the National Research Foundation of South Africa and the Olifants River Forum for provision of funding and unknown referees for critically reviewing the manuscript and suggesting useful changes.

\section{References}

American Public Health Association (APHA), American Water Works Association (AWWA), and Water Pollution Control Federation (WPCF), 1992: Standard 
methods for the examination of water and wastewater. $19^{\text {th }}$ ed. Washington DC, APHA, AWWA, USA: APHA, AWWA \& WPCF.

Abell, J.M., Özkundakci, D. \& Hamilton, D.P., 2010: Nitrogen and Phosphorus limitation of phytoplankton growth in New Zealand lakes: Implications for eutrophication control.- Ecosystems 13:966-977.

Bellinger, E.G. \& Sigee, D.C., 2010: Freshwater Algae: Identification and Use as Bioindicators, John Wiley \& Sons, Ltd, USA, Chapter 3, pp. 100-136.

Berger, W.H. \& Parker, F.L., 1970: Diversity of planktonic Foraminifera in deep sea sediments.- Science 168:1345-7.

Biggs, B.J.F., 2000: Eutrophication of streams and rivers: Dissolved nutrient-chlorophyll relationships for benthic algae.- J N Am Benthol Soc 19:17-31.

Born, S.M., 1979: Lake rehabilitation: A status report.- Environ Manage 3:145-153.

Bothwell, M.L., 1989: Phosphorus-limited growth dynamic of lotic periphytic diatom communities: Areal biomass and cellular growth rate responses.- Can J Fish Aquat Sci 46:1293-1301.

Breen, C.M., 1983: Limnology of Lake Midmar. Pretoria, South Africa: South African National Scientific Programmes Report no 78; pp. 1-134.

Biggs, B.J.F., 1996: Hydraulic habitat of plants in streams.- Regul River 12:131-144. 
Brower, J.E., Zan, J.H. \& von Ende, L.N.,1990: Species diversity. In: Brower, J.E., Zan, J.H. \& von Ende L.N. Methods for General Ecology, $3^{\text {rd }}$ ed. Dubuque, IA: William C. Brown Publishers; pp. 153-175.

Butty, M., Walmsley, R.D. \& Alexander, C.J., 1980: Loskop Dam. In: Walmsley RD \& Butty M, editors. The limnology of some selected South African impoundments. Pretoria, South Africa: National Institute for Water Research, CSIR; pp. 63-65.

Cabecinha, E., Cortes, R., Cabral, J., Ferreira, T., Lourenco, M. \& Pardal, M.A., 2009: Multiscale approach using phytoplankton as a first step towards the definition of the ecological status of reservoirs.- Ecol Indic 9: 240-255.

Caput, K, Burić, Z. \& Olujić, G., 2005: Vertical distribution of periphytic diatoms in the karstic Zrmanja River (Croatia). Acta Bot Croat 64, 227-236.

Carignam, R., 1982: An empirical model to estimate the relative importance of roots in phosphorus uptake by aquatic macrophytes.- Can J Fish Aquat Sci 39: 243-7.

Carney, 1994: In: Freshwater Microbiology; Biodiversity and Dynamic Intractions of microorganisms in Aquatic Environments (Sigee, D.C ed), John Wiley\& Sons Ltd, The Atrium, Southern Gate, Chichester West Sussex PO 1985 SQ, England, pp. 454-455.

Carpenter, S.R., Ludwig, D. \& Brock, W.A., 1999: Management of eutrophication for lakes subject to potentially irreversible change.- Ecol Appl 9: 559-568. 
Chutter, F.M., 1989: Evaluation of the impact of the $1 \mathrm{mg} \mathrm{l}^{-1}$ Phosphate-P standard on the water quality and trophic state of Hartbeespoort Dam. Pretoria, South Africa: Water Research Commission, WRC Report No. 181/1/89.

Correll, D.L., 1998: The role of phosphorus in the eutrophication of receiving waters: A review.- J Environ Qual 27: 261-266.

Das, S.K., Routh, J., Roychoudhury, A.N., Klump, J. \& Ranjan, R.K., 2009: Phosphorus dynamics in shallow eutrophic lakes: an example from Zeekoevlei, South Africa.Hydrobiologia 619:55-66.

De Villiers, S. \& Thiart, C., 2007: The nutrient status of South African rivers: Concentrations, trends and fluxes from the1970's to 2005.- S Afr J Sci 103: 343349.

Department of Water Affairs and Forestry (DWAF)., 2004: National Water Resource Strategy (NWRS). $1^{\text {st }}$ ed. Pretoria, South Africa.

DU Plessis, B.J., Howard, M.R. \& Bruwer, C.A,, 1990: Eutrophication, the trophic status of selected South African reservoirs. Hydrological Research Institute Report No N/0000/00/DEQ 1290, Pretoria, South Africa, pp. 1-148 
Driescher, A.C., 2008: A water quality study of Loskop Dam and the upper catchment of the Olifants River. Unpublished MSc. Thesis. University of the Free State, Bloemfontein, South Africa pp. 1-150.

Edmondson, W.T., 1990: The uses of ecology: Lake Washington and beyond. Seattle, WA: University of Washington Press.

Gieskes, J., 1960: Part 2: Hydrobiological survey of the Lake Loskop. Pretoria, South Africa: National Institute of Water Research. Project Report No.6/4h.

Gore, J.A., 2006: Discharge measurements and streamflow analysis. In: Hauer, F.R., Lamberti, G.A. editors. Methods in stream ecology. San Diego, California, USA: Academic Press; pp. 51-81.

Grobler, D.C., Kempster, P.L. \& Van der Merwe, L., 1994: A note on the occurrence of metals in the Olifants River, Eastern Transvaal, South Africa.- Water SA 20: 195205.

Hart, R.C., 2006: Food web (bio-) manipulation of South African reservoirs - viable eutrophication management prospect or illusory pipe dream? A reflective commentary and position paper.- Water 32: 567-575.

Hains, A.T., Finlayson, B.L. \& McMahon, T.A., 1988: A global classification of river regimes.- Appl Geogr 8: 255-272. 
Hilton, J., O’Hare, M., Bowes, M.J. \& Jones, J.I., 2006: How green is my river? A new paradigm of eutrophication in rivers.- Sci Total Environ 365: 66-83.

Hilton, J. \& Irons, G.P., 1998: Determining the cause of ‘apparent eutrophication' effects. Environment agency R\&D Technical Report P203; pp.1-21.

Jarvie, H.P., Williams, R.J. \& Neal, C., 2004: Assessing changes in phosphorus concentrations in relation to in-stream plant ecology in lowland permeable catchments: bringing ecosystem functioning into water quality monitoring.Water Air Soil Poll 4: 641-655.

Jeppesen, E., Jensen, J.P., Sondergaard, M. \& Lauridsen, T.L., 2000: Trophic structure, species richness and biodiversity in Danish lakes: Changes along a phosphorus gradient.- Freshwater Biol 45: 201-213.

Jeppesen, E., Jensen, J.P., Sondergaard, M. \& Lauridsen, T.L., 2005: Response of fish and plankton to nutrient loading reduction in eight shallow Danish lakes with special emphasis on seasonal dynamics.- Freshwater Biol 50: 1616-1627.

Kalff, J., 2002: Limnology: Inland water ecosystems. Upper Saddle River, New Jersey, USA: Prentice-Hall Inc; pp.1-592.

Kjeldsen, K., 2004: The relationship between phosphorus and peak biomass of benthic algae in small lowland streams.- Verh Internat Verein Limnol 25: 1530-3. 
Koning, N. \& Roos, J.C., 1999: The continued influence of organic pollution on the water quality of the turbid Modder River.- Water SA 25: 285-292.

Lakshminarayana, J.S.S., 1965: Study of the phytoplankton of the River Ganges, II: The seasonal growth and succession of the plankton algae in the River Ganges.Hydrobiologia 25: 138-165.

Marsden, M.W., 1989: Lake restoration by reducing external phosphorus loading: The influence of sediment release.- Freshwater Biol 21: 139-162.

McDowell, R.W., Biggs, B.J.F., Sharpley, A.N. \& Nguyen, L., 2004: Connecting phosphorus loss from agricultural landscapes to surface water quality.- Chem Ecol 20: 1-40.

Midgley, D.C., Pitman, W.V. \& Middleton, B.J., 1994: Surface water resources of South Africa 1990. Pretoria, South Africa: WRC report no. 298/4.1/94, Water Research Commission.

Mucina, L. \& Rutherfod, M.C., 2006: editors. The vegetation of South Africa, Lesotho and Swaziland. Strelitzia 19. Pretoria, South Africa: South African National Biodiversity Institute (SANBI).

Neal, C. \& Heathwaite, A.L., 2005: Nutrient mobility within river basins: A European perspective.- J Hydrol 304: 477- 490. 
Newton, B. \& Jarell, W.M., 1999: A procedure to estimate the response of aquatic systems to changes in phosphorus and nitrogen inputs. Portland, OR, USA: Natural Resources Conservation Service, National Water and Climate Center; pp. 1-37.

Nyenje, P.M., Foppen, J.W., Uhlenbrook, S., Kulabako, R. \& Muwanga, A., 2010: Eutrophication and nutrient release in urban areas of sub-Saharan Africa-A review.- Sci Total Environ 408: 447-455.

Oberholster, P.J., Botha, A-M. \& Cloete, T.E., 2007: Ecological implications of artificial mixing and bottom-sediment removal for a shallow urban lake, Lake Sheldon, Colorado.- Lakes Reservoirs: Res Manage 12: 73-78.

Oberholster, P.J., Botha, A-M. \& Ashton, P.J., 2009: The influence of a toxic cyanobacterial bloom and water hydrology on algal populations and macroinvertebrate abundance in the upper littoral zone of Lake Krugersdrift, South Africa.- Ecotoxicology 18: $34-41$.

Oberholster, P.J., Myburgh, J.G., Ashton, P.J. \& Botha, A-M., 2010: Responses of phytoplankton upon exposure to a mixture of acid mine drainage and high levels of nutrient pollution in Lake Loskop, South Africa.- Ecotoxicol Environ Safety 73: $326-335$.

Oberholster, P.J., $2011 \mathrm{a}$ : Using epilithic filamentous green algae communities as indicators of water quality in the headwaters of three South African river systems during 
high and medium flow periods. In: Kattel, G, editor. Zooplankton and Phytoplankton. Chapter 5. USA: Nova Science Publishers Inc; pp. 107-122.

Oberholster, P.J., Myburgh, J.G., Ashton, P.J., Coetzee, J.J. \& Botha, A-M., 2011b: Bioaccumulation of aluminium and iron in the food chain of Lake Loskop, South Africa.- Ecotoxicol Environ Safety 75: 134-141.

Pillay, M., 1994: Detergent phosphorus in South Africa: Impact on eutrophication with special reference to the Umgeni catchment. MSc Thesis. Department of Chemical Engineering, University of Natal, Durban, South Africa.

Porra, R.J., Thompson, W.A \& Kriedemann, P.E., 1989: Determination of accurate extinction coefficients and simultaneous equations for assaying chlorophylls a and b extracted with four different solvents: verification of the concentration of chlorophyll standards by atomic absorption spectrometry.- Biochim Biophys Acta 975: $384-394$.

Reynolds, C.S., 1984: Phytoplankton periodicity: the interactions of form, function and environmental variability.-Freshwat Biol 14: 111-142

Reynolds, C., 2007: Ecology of phytoplankton. Cambridge, UK: Cambridge University Press; pp. 413-5.

Rowntree, K.M., 1999: A hierarchical geomorphological model for the classification of selected South African Rivers. Water Research Commission, Pretoria, South Africa, WRC Report No 497/1/99, pp. 1-334. 
Sas, H., 1989: Lake restoration by reduction of nutrient loading: Expectations, experiences, extrapolation. St Augustin, Germany: Academia Verlag Richarz.

Scheffer, M., 1998: Ecology of shallow lakes. London: Chapman and Hall.

Stevenson, R.J. \& Bahls, L.L., 1999: Periphyton protocols. In: Barbour, M.T., Gerritren, J., Snyder, B.D. \& Stribling, J.B., editors. Rapid bioassessment protocols for use in streams and wadeable rivers: Periphyton, benthic macroinvertebrates and fish. $2^{\text {nd }}$ ed. Washington DC: USA EPA 841-B-99-002. United States Environmental Protection Agency; pp. 6-22.

Stockner, J.G. \& Benson, W.W., 1967: The succession of diatom assemblages in recent sediments of Lake Washington.- Limnol Oceanogr 12: 513-532.

Stockner, J.G., 1971: Preliminary characterization of lakes in the experimental lakes area, Northwestern Ontario, using diatom occurrences in sediments.- J Fish Res Board Can 28: 265-275.

Taylor, R., Best, H.J. \& Wiechers, H.N.S., 1984: The effluent phosphate standard in perspective. Part 1: Impact, control and management of eutrophication.- IMIESA 9: 43-56.

Taylor, J.C., Harding, W.R. \& Archibald, C.G.M., 2007: An illustrated guide to some common diatom species from South Africa. WRC Report, No. TT 282/07. Water Research Commission, Pretoria, South Africa, plates 1-178. 
Truter, E., 1987: An aid to the identification of the dominant and commonly occurring genera of algae observed in some South African impoundments. Pretoria, South Africa: Department of Water Affairs; pp. 1-97.

Thornton, J.A. \& Walmsley, R.D., 1982: Application of phosphorus budget models to South African man-made lakes.- Hydrobiologia 89: 237-245.

Toerien, D.F., Hyman, K.L. \& Bruwer, M.J., 1975: A preliminary trophic status classification of some South African impoundments.- Water SA 1: 15-23

Toerien, D., 1977: A review of eutrophication and guidelines for its control in South Africa. CSIR Special Report. Water 48.

Van Vuuren, S., Taylor, J.C., Gerber, A. \& Van Ginkel C., 2006: Easy identification of the most common freshwater algae. Pretoria, South Africa: North-West University and Department of Water Affairs and Forestry, pp. 1-200.

Vannote, R.L., Minshall, G.W., Cummins, K.W., Sedell, J.R. \& Cushing CE., 1980: The river continuum concept.- Can J Fish Aquat Sci 37: 130-7.

Walmsley, R.D. \& Butty, M., 1980: Limnology of some selected South African impoundments. Pretoria, South Africa: Water Research Commission (WRC), National Institute of Water Research (NIWR), CSIR, pp. 1-27 
Walmsley , R.D., 1984: A chlorophyll a trophic status classification system for South African impoundments.- J Environ Quality 13: 97-104.

Wehr, J.D. \& Sheath, R.G., 2003: Freshwater algae of North America, ecology and classification. San Diego, USA: Academic Press; pp. 775-804.

Withers, P.J.A. \& Jarvie, H.P., 2008: Delivery and cycling of phosphorus in rivers: A review. -Sci Total Environ 400: 379-395.

Yang, X., Wu, X. Hao, H. \& He, Z., 2008: Mechanisms and assessment of water eutrophication.- J Zhejiang Uni Sci 9: 197-209.

Zohary, T. \& Breen, C.M., 1989: Environmental factors favouring the formation of Microcystis aeruginosa hyperscums in a hypertrophic lake.- Hydrobiologia 178: 179-192. 